\title{
Comparative Studies Using Nanotechnology on Fungal Diseases Defense to Productivity Improvement of Squash Crop
}

\author{
Khaled A. Soubeih ${ }^{1}$ and Mohamed K. Agha ${ }^{2}$
}

\begin{abstract}
The objective of this paper was to study the effect of silicon dioxide $\left(\mathrm{SiO}_{2}\right)$ and titanium dioxide $\left(\mathrm{TiO}_{2}\right)$ nanoparticles NPs sprayed separate or in combination compare with traditional practices on plant ability to resist fungal diseases and improving growth and productivity of zucchini squash (Cucurbita pepo L.) crop in Al-Kantara Sharq experimental station located $30^{\circ} 49^{\prime} 41.4^{\prime \prime} \mathrm{N}$ and $32^{\circ}$ 24' 11.4" S, Eastern part of Al-Ismailia governorate within Sinai, Egypt during summer seasons of 2015 and 2016.

The treatments were: 1.Control spraying with distilled water $\left(\mathrm{T}_{1}\right)$, 2.Copper oxychloride $\mathrm{Cu}_{2}(\mathrm{OH})_{3} \mathrm{Cl}$ at concentration of $5000 \mathrm{ppm}\left(\mathrm{T}_{2}\right), 3 . \mathrm{SiO}_{2} 25 \mathrm{ppm}\left(\mathrm{T}_{3}\right), 4 . \mathrm{SiO}_{2}$ $50 \mathrm{ppm}\left(\mathrm{T}_{4}\right), 5 . \mathrm{TiO}_{2} 25 \mathrm{ppm}\left(\mathrm{T}_{5}\right), 6 . \mathrm{TiO}_{2} 50 \mathrm{ppm}\left(\mathrm{T}_{6}\right), 7 . \mathrm{SiO}_{2}$ $25 \mathrm{ppm}+\mathrm{TiO}_{2} 25 \mathrm{ppm}\left(\mathrm{T}_{7}\right), 8 . \mathrm{SiO}_{2} 25 \mathrm{ppm}+\mathrm{TiO}_{2}$ 50ppm $\left(\mathrm{T}_{8}\right)$, 9.SiO $\mathrm{Si}_{2} 50 \mathrm{pm}+\mathrm{TiO}_{2} 25 \mathrm{ppm}\left(\mathrm{T}_{9}\right)$ and $10 . \mathrm{SiO}_{2} 50 \mathrm{ppm}$ $+\mathrm{TiO}_{2}$ 50ppm $\left(\mathrm{T}_{10}\right)$.

The results indicated that incidence and severity of powdery and downy moilew significantly decreased with $\mathrm{SiO}_{2}$ NPs whether sprayed at low or high concentration or if it was separate or in mixed with $\mathrm{TiO}_{2} \mathrm{NPs}$ when compared with control $\left(T_{1}\right)$. Powdery mildew not response to individual sprayed $\mathrm{TiO}_{2}$ NPs but in opposite, incidence and severity of downy moilew significantly decreased with increasing $\mathrm{TiO}_{2} \mathrm{NPs}$ concentration. up to $50 \mathrm{ppm}$ compared with control.
\end{abstract}

The obtained results revealed that foliar application with the tested materials include $\mathrm{Cu}_{2}(\mathrm{OH})_{3} \mathrm{Cl}$ compared with control showed significant effect on all studied morphological growth characters, yield components and marketable yield as well as photosynthetic pigments and nitrogen, phosphorus and potassium (NPK) contents. Results refer that individual $\mathrm{TiO}_{2} \mathrm{NPs}_{\text {shether in low or }}$ high concentration achieved superior promotion than $\mathrm{SiO}_{2}$ NPs on vegetative growth characters which expressed as shoot height, number of branches and leaves plant ${ }^{-1}$, largest leaf area, fresh and dry weight plant $^{-1}$ and dry matter percentage, while the maximum values were attained from $T_{10}$ compared with $T_{1}$ and $T_{2}$. Furthermore, no significant effects were recorded between $T_{10}, T_{8}, T_{6}, T_{5}, T_{9}$ and $T_{7}$ but there were achieved the highest values of fresh and dry fruit weight and fruit dry matter percentage when compared with control while the highest number of fruits were attained from all tested materials except, $\mathrm{TiO}_{2} \mathrm{NPs}_{\text {. }}$ Subsequently, control treatment and $\mathrm{TiO}_{2} \mathrm{NPs}$ in low or high concentration whether individual or in combination with low concentration of $\mathrm{SiO}_{2}$ NPs significantly produced

DOI: 10.21608/ASEJAIQJSAE.2019.29730

${ }^{1}$ Department of Plant Production, Desert Research Center - Cairo, Egypt.

2-Department of Plant Protection, Desert Research Center - Cairo, Egypt.

E-mail:* soubeihk@yahoo.com

Received February 17, 2019, Accepted March 30, 2019 the highest heavy fruit weight per plant and plot while the lowest un-marketable fruit weights and number were achieved from foliar sprayed $\mathrm{SiO}_{2} \mathrm{NPs}$ with their concentrations in addition to $\mathbf{T}_{10}$. For what it was no significant differences were found between $T_{10}, T_{2}, T_{9}, T_{8}$, $\mathbf{T}_{7}, \mathbf{T}_{4}$ and $\mathbf{T}_{3}$ treatments, there achieved the maximum production whether per plant, plot or feddan as well as marketable yield compared with control treatment. Spraying $\mathrm{SiO}_{2}$ NPs at concentration of $50 \mathrm{ppm}$ achieved minimum un-marketable yield. Chemically, photosynthetic pigments, $\mathrm{NO}_{3}^{-}, \mathrm{P}_{2} \mathrm{O}_{5}^{--}$and $\mathrm{K}^{+}$contents significantly increased with all treatments compared with control while the highest accumulate in plant tissues were gotten from $\mathbf{T}_{10}$. Anatomically, results and photomicrograph indicated that thin epidermis layers surrounded malformed and destroyed palisade and spongy tissues as a result to fungal diseases infection were observed in untreated plants (control). On opposite, leaf thickness and upper and lower epidermis layers as well as space area $(\%)$ were increased when plants treated with separate or mixing at low or high concentration $\mathrm{SiO}_{2}$ and $\mathrm{TiO}_{2}$ NPs compared with control or cupper oxychloride. Also, of observation that $\mathrm{TiO}_{2} \mathrm{NPs}_{3}$ increased photosynthetic cortical and exchangeable gas spaces more than $\mathrm{SiO}_{2}$ NPs which increased cell wall thickness. The maximum leaf thickness, palisade length, sponge length, upper epidermis thickness, lower epidermis thickness and area space $(\%)$ were attained from $\mathbf{T}_{10}, \mathbf{T}_{6}$, $\mathbf{T}_{8}, \mathbf{T}_{6}, \mathbf{T}_{6}$ and $\mathbf{T}_{6}$.

Key words: Zucchini squash (Cucurbita pepo L.), silicon dioxide nanoparticle, titanium dioxide nanoparticle, Powdery mildew, Downy mildew.

\section{INTRODUCTION}

Zucchini squash (Cucurbita pepo L.) is one of the most important Cucurbitaceae family plants and is one of popularity vegetable crops in Egypt. Squash, cucumber, crab apples, grapes, lilacs, monarda, roses and phlox are all likely targets for downy and powdery mildew which causes leaf curling, yellowing, premature defoliation and in some cases death of the plant. However, using constant fungicides result in resistant populations of the pathogens and environmental pollution (McGrath et.al, 1996).

The increment of yield and improving quality of zucchini squash is depending on many factors such as suitable climate, fertility soil have good drainage, fresh 
water and good agricultural practices on suitable plant variety, those have been led to diseases resistance, enhancing plant growth, increase fruit set and improving crop quality and productivity.

The material properties can be change if it form or size changed. Nano is a unit equal a billionth of a meter. Nano-particle is every particle has at least one dimension 1 - $100 \mathrm{~nm}$ (Ball, 2002). Nanoparticles (NPs) have unique physicochemical properties i.e., high surface area, high reactivity, tunable pore size and particle morphology for that, it can open a large scope of novel application in biotechnology and agricultural industries through containing herbicides, nano-pesticide, fertilizers or genes which target specific cellular organelles in plants to release their content (Siddiqui et al., 2015).

The soils are content high amount of silicon with an average of $28 \% \mathrm{Si}$ by weight. Silicon dioxide, aluminosilicates and silicate minerals are consists of the vast majority of $\mathrm{Si}$ compounds in the soil, none of which are available for plant uptake. The only plant bioavailable silicon compound is monosilicic acid (MSA) with synonym orthosilicic acid (OSA), the concentration of which is very low in the soil, it's meanly found in sea water and rivers water (Laane, 2018). MSA is found in dynamic equilibrium with disilicic acid, which is considered the bioavailable form of silicon. Silicates are salts of silicic acid used as fertilizers like calcium silicate, potassium silicate, sodium silicate and combinations of diatomaceous earth with minerals. The plants are classified according to contain $\mathrm{Si}$, accumulators plants, intermediate types, or $\mathrm{Si}$ excluder types Takahashi, et al. 1990). The differences are back to roots capacity to absorb MSA (Ma, et al., 2003). Monocotyledonous plants are active to uptake and classified as MSA accumulators. The soluble uptake MSA deposited in plant mainly in epidermal cell walls, middle lamellae, and intercellular spaces within sub epidermal tissues, beneath the cuticle in epidermal cell walls, in the outer regions of epidermal cell walls as biogenic opal (Sangster, et. al., 2001; Kim et al., 2002 and Canny, 2006). Sufficient uptake of MSA exerts many beneficial effects on plants because it's play an active role in the uptake of other plant nutrients, structural strength, leaves resistance to blast, enhancing growth and development especially when plants are exposed to abiotic stresses like drought, salinity, acidity, etc. and biotic stresses, because $\mathrm{Si}$ increases plant resistance by stimulating defense reaction mechanism (Kim et al., 2002; Fauteux, et al., 2005 and Shallan et al.,2016). Also, decreasing damage from insects and rodents due to the fortification of the plant, acting also as a functional deterrent to herbivore. In this respect, using silicate compounds as fungal resistance, Guével, et al. (2007) cleared that accumulate $\mathrm{Si}$ in wheat leaves resulted in a maximum reduction of powdery mildew disease severity of $80 \%$. Also, the foliar sprays of $\mathrm{KSi}$ reduced the powdery mildew significantly, but less than the root-applied. Also, Wolff, et al. (2012) reported that one or two foliar sprays of potassium silicate at concentration of 28 and $56 \mathrm{mM}$ were applied to cucumbers plants reduced the powdery mildew infection rates by up to $87 \%$. Also, Rangaraj et, al. (2014) reported that maize treated with nanosilica recorded significantly higher resistance to Aspergillus spp. than with bulk silica.

Regarding to the effect of silicate application on plants, Guével, et al. (2007) found that soil- and foliarapplied KSi did not effect in wheat growth, but foliar stabilized silicic acid sprays showed growth-promoting effects, resulting in significantly taller plants. Suriyaprabha et al. (2014) found that silica nanoparticles $(20-40 \mathrm{~nm})$ significantly increased the concentrations of organic compounds and silica contents in maize when compared to the silicate treatment in a pot study, while, the soil application of silicates appeared to be more effective than the foliar Si NPs. Janmohammadi et al. (2016) found that Si NPs foliar sprays on Safflower, significantly improved canopy spread, stem diameter, plant height, ground cover and the number of achene, while, there was no effect on the achene yield or the harvest index. Also, Shwethakumari (2017) showed that three sprays of stabilized silicic acid with concentrations of $2 \mathrm{~mL} / \mathrm{L}$ ( 15 or $30 \mathrm{ppm} \mathrm{Si}$ ) on soybean increased the plant height, number of leaves, pod and seed yield. Also, the protein and oil yield significantly increased with same treatment. Furthermore in a field study, Yassen, et al. (2017) found that spraying $\mathrm{Si} \mathrm{NPs}$ at concentration of $60 \mathrm{mg} / \mathrm{L}$ increased cucumber growth parameters expressed as plant height, number of leaves/plant, fresh and dry weight of leaves/plant as well as number of fruits/plant, mean weight of fruit and fruit length and in turn yield of plant and total yield /ha when compared to untreated plants.

A large number of studies on the effects of titanium dioxide NPs on germination and growth of plants have been documented. In this respect, Lu et al. (2002) found that the nitrate reductase activity and stimulated antioxidant system improved in soybean by the mixture of $\mathrm{TiO}_{2}$ and $\mathrm{SiO}_{2} \mathrm{NPs}$. Hong et al. (2005) and Zheng et al. (2005) reported that the treatments of $\mathrm{TiO}_{2} \mathrm{NPs}$ on spinach increased germination, photosynthesis, chlorophyll formation and plant dry weight. Furthermore, Singh et al., (2010) studied the biological and physical changes of Brassica oleracea in presence 
of $\mathrm{TiO}_{2} \mathrm{NPs}(5-8 \mathrm{~nm})$ at concentration of $0.05-2 \mathrm{~mL}$ in $500 \mathrm{~mL}$ of hoagland solution, they found that the high concentrations had negative impact on shoot length whereas positive impact on root length of broccoli. In addition, Dehkourdi and Mosavi (2013) reported that soaked parsley seeds or sprayed plants by $\mathrm{TiO}_{2}$ NPs enhanced germination and promoted plant growth where seedling shoot and root length and chlorophyll content increased. Also, Feizi et al. (2013) found that the germination rate of salvia improved when the seeds were treated with $\mathrm{TiO}_{2} \mathrm{NPs}$.

Laware and Raskar (2014) found that $\mathrm{TiO}_{2}$ at lower concentration (10 and $20 \mu \mathrm{g} \mathrm{mL} \mathrm{m}^{-1}$ ) enhanced seed germination and seedlings growth in onion and however the germination and growth showed inhibition at higher concentrations (40 and $50 \mu \mathrm{g} \mathrm{mL}^{-1}$ ). The $\mathrm{TiO}_{2}$ NPs also induced significant changes in activities of hydrolytic and antioxidant enzymes. Activities of amylase and protease were enhanced in lower concentration, but showed decrease at higher concentrations. Finally, Jiang et al. (2017) reported that jasmonic acid (JA) content in wheat seedling increased according to $\mathrm{TiO}_{2}$ nanoparticles applied, also they found that $\mathrm{Ti}$ accumulation showed a dose response manner in both wheat shoots and roots as $\mathrm{TiO}_{2}$ NPs concentrations increased. Also, Farhat et.al. (2018) tested nanoparticles of silicon and titanium synthesized biologically from different bacterial and fungal isolates. They found that Si NPs and Ti NPs as soaking and subsequent foliar spray against powdery mildew on wheat seedling reduced the powdery mildew severity in range 83.3 to $91.0 \%$ according to used microbe synthesized.

The aim of this investigation was to study the effect of silicon dioxide $\left(\mathrm{SiO}_{2}\right)$ and titanium dioxide $\left(\mathrm{TiO}_{2}\right)$ nanoparticles NPs sprayed separate or in combination compare with traditional antifungals compounds and testing their ability on plant to resist fungal diseases and improving growth and crop production of zucchini squash (Cucurbita pepo L.) crop $c v$. Rosena under Egyptian environmental conditions.

\section{MATERIALS AND METHODS}

An experiment was conducted at Al-Kantara Sharq experimental station located $30^{\circ} 49^{\prime} 41.4^{\prime \prime} \mathrm{N}$ and $32^{\circ} 24^{\prime}$ 11.4" S, Eastern part of Al-Ismailia governorate within Sinai for comparative study of nanoparticles and commercial fungicides in face of some fungal zucchini squash diseases to improve crop productivity.

Traditional agricultural practices, i.e., fertilization, irrigation, weeds and pest control were applied on zucchini squash Rosena cultivar during two consecutive summer seasons of 2015 and 2016 until to first true two leaves then the following treatments were applied:

1. Control spraying with distilled water $\left(\mathrm{T}_{1}\right)$.

3. $\mathrm{SiO}_{2} 25 \mathrm{ppm}\left(\mathrm{T}_{3}\right)$.

5. $\mathrm{TiO}_{2} 25 \mathrm{ppm}\left(\mathrm{T}_{5}\right)$.

7. $\mathrm{SiO}_{2} 25 \mathrm{ppm}+$ $\mathrm{TiO}_{2} 25 \mathrm{ppm}\left(\mathrm{T}_{7}\right)$.

9. $\mathrm{SiO}_{2} \quad 50 \mathrm{ppm}+$ $\mathrm{TiO}_{2} 25 \mathrm{ppm}\left(\mathrm{T}_{9}\right)$.

The used nanoparticles (NPs) were prepared and tested in laser research institute according to the methods described by Tacchini, et al. (2011). $\mathrm{SiO}_{2}$ and $\mathrm{TiO}_{2}$ NPs powders were amorphous (50-56 and 30-36 nm) with 99.9 and $98.6 \%$ purity respectively. NPs and the recommended dose of copper oxychloride (5000 ppm) were sprayed four times with 15 days intervals.

Complete block randomized design with three replicates was applied. Experimental plot was consisted of five ridges each of 3 meters long and 0.7 meter wide forming a plot area of $10.5 \mathrm{~m}^{2}$. The distance between holes within the row was about $50 \mathrm{~cm}$.

Physical and chemical analysis of the experimental soil used were estimated according to the methods described by Piper (1950) and Jackson (1962) respectively, while irrigation water analysis was determined by methods of Richards (1954) as shown in Tables (A,B and C).

Table A. Mechanical properties of the experimental soil

\begin{tabular}{|c|c|c|c|c|c|c|}
\hline ô & $=\tilde{z}$ & Coarse sand & Fine sand & silt & Clay & $\begin{array}{c}\text { Class } \\
\text { Texture }\end{array}$ \\
\hline$\ddot{\varpi}$ & שَ & \multicolumn{5}{|c|}{$\%$} \\
\hline $\begin{array}{l}1^{\text {st }} \\
2^{\text {nd }}\end{array}$ & $0-40$ & $\begin{array}{l}29.33 \\
26.89 \\
\end{array}$ & $\begin{array}{l}46.51 \\
49.83 \\
\end{array}$ & $\begin{array}{l}14.65 \\
13.02 \\
\end{array}$ & $\begin{array}{c}9.51 \\
10.26 \\
\end{array}$ & $\begin{array}{l}\text { Sandy loam } \\
\text { Sandy loam }\end{array}$ \\
\hline
\end{tabular}


Table B. Chemical analysis of the experimental soil

\begin{tabular}{|c|c|c|c|c|c|c|c|c|c|c|c|c|}
\hline \multirow{3}{*}{ 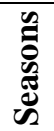 } & \multirow{3}{*}{ 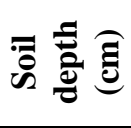 } & \multirow{3}{*}{$\mathbf{p H}$} & \multirow{3}{*}{ 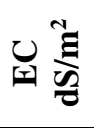 } & \multirow{3}{*}{$\begin{array}{c}\mathrm{CaCO}_{3} \\
(\%)\end{array}$} & \multicolumn{8}{|c|}{ Saturation soluble extract } \\
\hline & & & & & \multicolumn{4}{|c|}{ Soluble anions (ppm) } & \multicolumn{4}{|c|}{ Soluble Cations (ppm) } \\
\hline & & & & & $\mathrm{CO}_{3}^{-2}$ & $\mathrm{HCO}_{3}$ & $\mathrm{SO}_{4}^{-2}$ & $\mathrm{Cl}^{-}$ & $\mathrm{Ca}^{++}$ & $\mathrm{Mg}^{++}$ & $\mathrm{Na}^{+}$ & $\mathrm{K}^{+}$ \\
\hline $1^{\text {st }}$ & & 7.37 & 1.62 & 12.31 & - & 45.7 & 157.8 & 542.3 & 55.4 & 43.1 & 268.1 & 34.2 \\
\hline $2^{\text {nd }}$ & $0-40$ & 7.21 & 1.44 & 10.05 & - & 27.4 & 137.2 & 488.7 & 41.3 & 31.0 & 249.5 & 21.1 \\
\hline
\end{tabular}

Table C. Chemical analysis of the irrigation water

\begin{tabular}{ccccccccccc}
\hline \multirow{2}{*}{ Season } & \multirow{2}{*}{$\mathbf{~}$} & $\begin{array}{c}\mathbf{E C} \\
\mathbf{d S} / \mathbf{m}\end{array}$ & \multicolumn{3}{c}{ Soluble anions (ppm) } & \multicolumn{3}{c}{ Soluble cations (ppm) } \\
\cline { 3 - 10 } & & $\mathbf{C O}_{3}{ }^{-}$ & $\mathbf{H C O}_{3}{ }^{-}$ & $\mathbf{S o 4}^{-2}$ & $\mathbf{C l}^{-}$ & $\mathbf{C a}^{++}$ & $\mathbf{M g}^{++}$ & $\mathbf{N a}^{+}$ & $\mathbf{K}^{+}$ \\
\hline $1^{\text {st }}$ & 7.12 & 2.22 & - & 57.50 & 294.3 & 602 & 98.4 & 61.4 & 547.8 & 16.4 \\
$2^{\text {nd }}$ & 7.10 & 2.07 & - & 55.5 & 380.2 & 540.1 & 88.8 & 87.6 & 319.5 & 21.1 \\
\hline
\end{tabular}

\section{Data recorded:}

\section{Pathogenic measurements:}

Before and after each spray date, the disease incidence and severity of powdery mildew and downy mildew were recorded. Disease incidence percentage (D.I) was calculated according to following formula:

$$
\text { Disease incidence (D.I.) }=\frac{\text { No. of infected plants }}{\text { Total plants }} \times 100
$$

The disease severity was recorded on 0 - 5 scale. Five infected leaves were collected from each one of randomly selected five infected plants in experimental unit for scoring data of disease severity as described by Singh, 2004. Percent of disease severity (PDS) was calculated by using the following formula:

$$
\text { PDS }=\frac{\text { Sum of all disease rating }}{\text { Total no. of rating } x \text { Maximum disease grade }} \times 100
$$

Table D. Score chart for disease severity of powdery mildew and downy mildew on leaves

\begin{tabular}{cl}
\hline Disease grade & \multicolumn{1}{c}{ Disease severity } \\
\hline 0 & No infection \\
1 & $0.1-1.0$ per cent leaf area affected \\
2 & $1.1-10.0$ per cent leaf area affected \\
3 & $10.1-25.0$ per cent leaf area \\
& affected \\
4 & $25.1-50.0$ per cent leaf area affected \\
5 & $<50.1$ per cent leaf area affected \\
\hline
\end{tabular}

\section{Plant measurements:}

1- Morphological vegetative growth characteristics: Five plant from each experimental plot at 75 days old from sowing zucchini squash seeds were randomly selected for plant growth measurements were expressed as: Plant height $(\mathrm{cm})$ which measured from cotyledonary node up to the upper most point of the plant, number of secondary branches per plant, number of leaves per plant, fourth leaf area per plant $\left(\mathrm{cm}^{2}\right)$ using leaf area meter, fresh and dry weight of shoot per plant $(\mathrm{g})$ and dry matter (\%) was calculated.
2- Anatomical studies: The anatomical studies were for more light on structure changes of zucchini squash leaves tissues i.e. leaf thickness $(\mu \mathrm{m})$, palisade length $(\mu \mathrm{m})$, sponge length $(\mu \mathrm{m})$, upper epidermis thickness $(\mu \mathrm{m})$, lower epidermis thickness $(\mu \mathrm{m})$ and area space (\%) in response to the different treatments . Leaves samples were taken after 75 days from sowing cleaned and cut to suitable parts and fixed in fixing solution. The sections were prepared according to the method described by Johansen (1940).

3- Yield and its components: At a horticultural maturity, when the fresh fruit was about $15 \mathrm{~cm}$, average of fruit number per plant, average of fruit weight and dry matter content, average yield/plant and average of total yield/fed. were measured.

4- Chemical assay : Total chlorophyll content was measured in fourth upper leaf using minolta chlorophyll meter SPAD-502. Also, nitrogen, phosphorus and potassium were determined in representative samples of fruit dry matter according to the methods of Peach and Tracey (1959), Frie et. al. (1964) and Brown and Lilliland (1964) for N, P and $\mathrm{K}$, respectively.

\section{Statistical analysis:}

Data were subjected to statistical analysis by costat (Russel, 1991). The differences among means were performed using least significant difference range (LSR) at 5\% level. The results of both investigated seasons were tested for homogeneity for applying combined analysis.

\section{RESULTS AND DISCUSSION}

Effect of nanoparticles foliar treatments against powdery mildew and downy mildew disease:

NPs are a modern uses technique in agriculture. The application of tested $\mathrm{SiO}_{2}$ and $\mathrm{TiO}_{2} \mathrm{NPs}$ separate or in combination as foliar treatments are significantly effective in both diseases incidence and severity of 
powdery mildew and downy mildew under field conditions during two successive growing seasons. Data presented in Table 1 indicated that $\mathrm{SiO}_{2} \mathrm{NPs}$ whether at low or high concentration significantly reduced both diseases incidence and severity when compared with control. While tested concentrations of $\mathrm{TiO}_{2} \mathrm{NPs}$ resulted in no significant differences were found on powdery mildew but, downy mildew significantly decreased when they compared with control treatment. The mixture treatments were significantly reduced both powdery mildew and downy mildew diseases incidence and severity. The maximum decreasing in both diseases incidence and severity were achieved from $T_{10}$ $\left(\mathrm{SiO}_{2} 50 \mathrm{ppm}+\mathrm{TiO}_{2} 50 \mathrm{ppm}\right)$ followed by $\mathrm{T}_{9}$ $\left(\mathrm{SiO}_{2} 50 \mathrm{ppm}+\mathrm{TiO}_{2} 25 \mathrm{ppm}\right)$ and $\mathrm{T}_{8}$ $\left(\mathrm{SiO}_{2} 25 \mathrm{ppm}+\mathrm{TiO}_{2} 50 \mathrm{ppm}\right)$ for powdery mildew. While were attained from $T_{10}$ followed $T_{2}$ then $T_{9}$ for downy mildew. These results agree with those found by Kim et al., (2002), Rangaraj et. al. (2014) and Farhat et.al. (2018). These results may be due to silica NPs has been benefit plant in number of ways: (1) enhanced host resistance to fungi due to the accumulation and polymerization of silicic acid in cell walls and rapidly emerging infected area in plant (2) increasing canopy photosynthesis by keeping leaves erect (3) reducing the toxicity of heavy metals (4) reducing rate of transpiration (Ali et. al., 2015; Elsharkawy et. al., 2015 and Jiang et al., 2017)

\section{Effect of NPs foliar treatments on zucchini squash crop:}

\section{A. Morphological vegetative growth characteristics:}

Data presented in Table 2 indicated that all treatments significantly increased all growth parameters when compared with control treatment. Data cleared that individual $\mathrm{TiO}_{2} \mathrm{NPs}$ treatments whether if at low or high concentration led to superior increases in all growth parameters when compared on $\mathrm{SiO}_{2}$ NPs. The mixture of $\mathrm{TiO}_{2}$ and $\mathrm{SiO}_{2}$ NPs promoted growth parameters to more enhancements which led to achieved the highest values compared with control and $\mathrm{Cu}_{2}(\mathrm{OH})_{3} \mathrm{Cl}$ as a traditional practices. The highest values attained of $\mathrm{T}_{10}$ for shoot height, number of branches and leaves plant ${ }^{-1}$, largest leaf area, fresh and dry weight plant $^{-1}$ and dry matter percentage were 66.3, 94.4, 78.9, 79.1, 227.1, 278.9 and $15.8 \%$, respectively above control treatment and were 9.6, 42.7, 23.1, 22.9, 60.3, 77.1 and $10.7 \%$, respectively above plants treated with $\mathrm{Cu}_{2}(\mathrm{OH})_{3} \mathrm{Cl}$. These results agree with those found by Dehkourdi and Mosavi (2013), Feizi et al. (2013) and Laware and Raskar (2014). These results may be due to that $\mathrm{TiO}_{2}$ NPs can activate the bio-metabolism process when promote forming the enzymes, hormones and some vital amino acids, in turn increase plant growth parameters (Jiang et al., 2017). Also, NPs mixtures of $\mathrm{SiO}_{2}+\mathrm{TiO}_{2}$ may be can increase plant growth parameters among to plant diseases resistance promoting and increase vital plant components which reduced disease incidence and accumulated dry matter in plant tissues (Lu et al., 2002; Ali et. al., 2015 and Elsharkawy et. al., 2015).

\section{B. Plant anatomical characteristics:}

Data presented in Table 3 revealed that leaves tissues significantly affected with investigated treatments where leaves thickness were reached to maximum increases when plants sprayed with $\mathrm{TiO}_{2} \mathrm{NPs}$ at low or high concentration individual or in mixture with $\mathrm{SiO}_{2}$ NPs concentrations. Picture (A) in Figure 1 refer to malformation and destroying photosynthetic cortical (palisade tissue), parenchyma cells (spongy tissues), thinness upper and lower epidermis and decreasing intercellular space due to fungal disease effect which in turn reduce leaf thickness when plants not treated with fungicides or other material can decrease fungal diseases. On opposite, picture (B) and Table 3 cleared that leaf in good healthy case where palisade and spongy tissues were appeared, leaf thickness and upper and lower epidermis layers as well as space area (\%) were increased when plants treated with $\mathrm{Cu}_{2}(\mathrm{OH})_{3} \mathrm{Cl}$ compared with control treatment.

Furthermore, palisade and spongy tissues and protection layers as well as intercellular space in turn leaf thickness increased in sequenced plants treated with separate or mixing at low or high concentration silicon and titanium nanoparticles compared with control or cupper oxychloride; but the observation, $\mathrm{TiO}_{2} \mathrm{NPs}$ increased palisade tissue (photosynthetic cortical) and intercellular space (exchangeable gas spaces) more than $\mathrm{SiO}_{2}$ NPs which increased cell wall thickness (Table 3 and pictures $\mathrm{C}$ and $\mathrm{D}$ in Figure 1). These results explained why plants treated with $\mathrm{TiO}_{2}$ NPs have been including photosynthetic pigments and their ability to increase plant growth more than $\mathrm{SiO}_{2} \mathrm{NPs}$ in this study. The absolute maximum values of leaf thickness, palisade length, sponge length, upper epidermis thickness, lower epidermis thickness and area space $(\%)$ were attained from $\mathrm{T}_{10}, \mathrm{~T}_{6}, \mathrm{~T}_{8}, \mathrm{~T}_{6}, \mathrm{~T}_{6}$ and $\mathrm{T}_{6}$ respectively. These results are agree with those reported by Ali et al. (2015); Elsharkawy et. al. (2015) who found that microscopic observations revealed that silica nanoparticles caused damage effects on fungal structures of rose powdery mildew. 
Table 1.Effect of nanoparticles foliar treatments on diseases incidence and severity

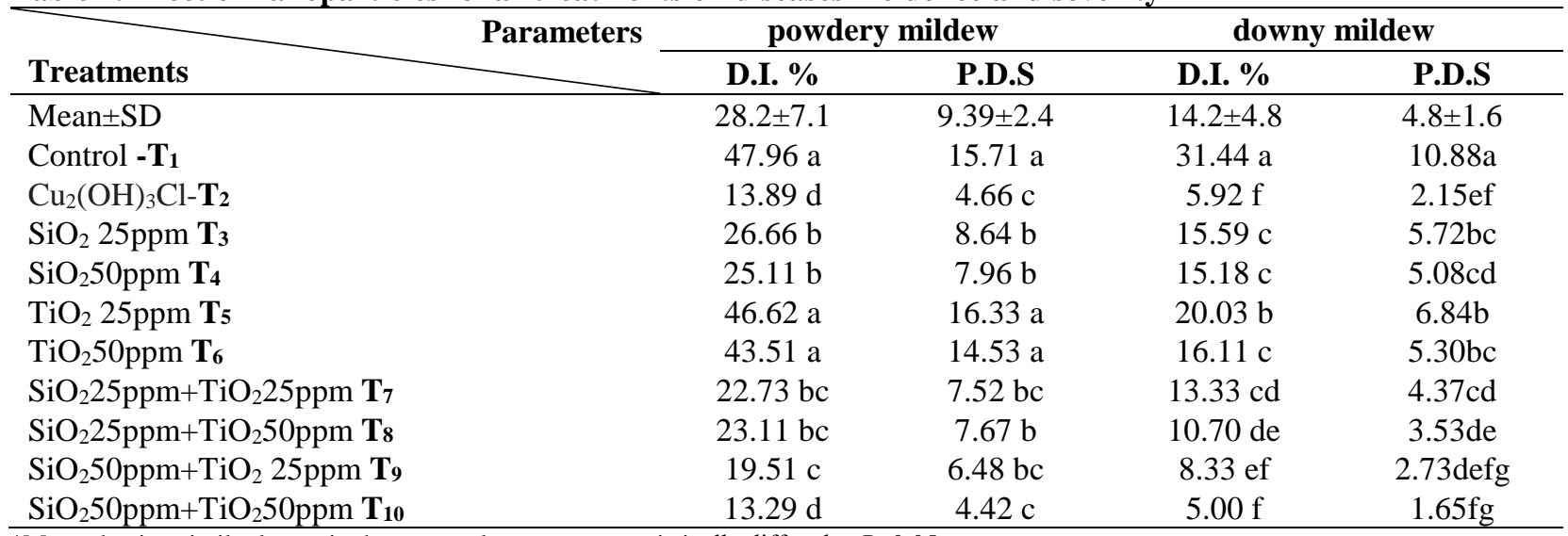

*Means having similar letters in the same column are not statistically differed at $\mathrm{P} \geq 0.05$.

Table 2.Effect of nanoparticles on growth parameters of zucchini squash $\mathrm{cv}$. Rosena

\begin{tabular}{|c|c|c|c|c|c|c|c|}
\hline \multirow{2}{*}{ Treatments } & \multirow{2}{*}{$\begin{array}{l}\text { Shoot } \\
\text { height } \\
(\mathrm{cm})\end{array}$} & \multirow{2}{*}{$\begin{array}{c}\text { No. } \\
\text { branches } \\
\text { plant }^{-1}\end{array}$} & \multirow{2}{*}{$\begin{array}{l}\text { No. } \\
\text { leaves } \\
\text { plant }^{-1}\end{array}$} & \multirow{2}{*}{$\begin{array}{c}\text { Fourth } \\
\text { leaf } \\
\text { area } \\
\text { cm }^{2} \\
\end{array}$} & \multicolumn{2}{|c|}{ Weight g plant ${ }^{-1}$} & \multirow{2}{*}{$\begin{array}{c}\text { Dry } \\
\text { matter } \\
\%\end{array}$} \\
\hline & & & & & Fresh & Dry & \\
\hline Mean \pm SD & $56.0 \pm 2.6$ & $5.8 \pm 0.5$ & $\begin{array}{c}23.6 \pm \\
2.0\end{array}$ & $\begin{array}{c}253.3 \pm \\
30.2\end{array}$ & $\begin{array}{c}1597.3 \pm \\
259.7\end{array}$ & $\begin{array}{c}345.9 \pm \\
58.7\end{array}$ & $\begin{array}{c}21.5 \pm \\
0.6\end{array}$ \\
\hline Control $-\mathbf{T}_{\mathbf{1}}$ & $38.3 \mathrm{~g}$ & $3.6 \mathrm{f}$ & $15.2 \mathrm{c}$ & $227.5 \mathrm{c}$ & $691.3 \mathrm{f}$ & $135.3 \mathrm{e}$ & $19.6 \mathrm{e}$ \\
\hline $\mathrm{Cu}_{2}(\mathrm{OH})_{3} \mathrm{Cl}-\mathbf{T}_{\mathbf{2}}$ & $58.1 \mathrm{~cd}$ & $4.9 \mathrm{~d}$ & $22.1 \mathrm{~b}$ & $331.5 \mathrm{~b}$ & $1410.9 d$ & $289.5 \mathrm{~cd}$ & $20.5 \mathrm{~d}$ \\
\hline $\mathrm{SiO}_{2} 25 \mathrm{ppm} \mathbf{T}_{\mathbf{3}}$ & $49.0 \mathrm{f}$ & $4.2 \mathrm{e}$ & $20.7 \mathrm{~b}$ & $310.0 \mathrm{~b}$ & $1169.1 \mathrm{de}$ & $249.3 \mathrm{~d}$ & $21.3 \mathrm{c}$ \\
\hline $\mathrm{SiO}_{2} 50 \mathrm{ppm} \mathbf{T}_{4}$ & $53.6 \mathrm{e}$ & $5.0 \mathrm{~d}$ & $20.5 \mathrm{~b}$ & $307.5 \mathrm{a}$ & $1131.5 \mathrm{e}$ & $248.3 \mathrm{~d}$ & $21.9 \mathrm{bc}$ \\
\hline $\mathrm{TiO}_{2} 25 \mathrm{ppm} \mathbf{T}_{\mathbf{5}}$ & $56.4 \mathrm{~d}$ & $6.2 \mathrm{c}$ & $25.3 \mathrm{a}$ & $380.0 \mathrm{a}$ & $1723.2 \mathrm{c}$ & $368.7 b c$ & $21.4 \mathrm{c}$ \\
\hline $\mathrm{TiO}_{2} 50 \mathrm{ppm} \mathbf{T}_{6}$ & $57.5 \mathrm{~cd}$ & $6.8 \mathrm{ab}$ & $26.0 \mathrm{a}$ & $390.0 \mathrm{a}$ & $1750.0 \mathrm{bc}$ & $378.9 \mathrm{bc}$ & $21.6 \mathrm{c}$ \\
\hline $\mathrm{SiO}_{2} 25 \mathrm{ppm}+\mathrm{TiO}_{2} 25 \mathrm{ppm} \mathbf{T}_{7}$ & $59.8 \mathrm{bc}$ & $6.2 \mathrm{c}$ & $25.8 \mathrm{a}$ & $387.5 \mathrm{a}$ & $1854.9 \mathrm{bc}$ & $395.8 b c$ & $21.3 \mathrm{c}$ \\
\hline $\mathrm{SiO}_{2} 25 \mathrm{ppm}+\mathrm{TiO}_{2} 50 \mathrm{ppm} \mathbf{T} \mathbf{8}$ & $61.7 \mathrm{ab}$ & $7.2 \mathrm{a}$ & $26.7 \mathrm{a}$ & $400.0 \mathrm{a}$ & $2015.1 \mathrm{ab}$ & $440.8 b c$ & $21.9 \mathrm{bc}$ \\
\hline $\mathrm{SiO}_{2} 50 \mathrm{ppm}+\mathrm{TiO}_{2} 25 \mathrm{ppm} \mathbf{T}_{\mathbf{9}}$ & $62.4 \mathrm{a}$ & $6.5 \mathrm{bc}$ & $26.1 \mathrm{a}$ & $391.5 \mathrm{a}$ & $1965.9 b c$ & $440.3 \mathrm{ab}$ & $22.4 \mathrm{ab}$ \\
\hline $\mathrm{SiO}_{2} 50 \mathrm{ppm}+\mathrm{TiO}_{2} 50 \mathrm{ppm} \mathbf{T}_{\mathbf{1 0}}$ & $63.7 \mathrm{a}$ & $7.0 \mathrm{ab}$ & $27.2 \mathrm{a}$ & $407.5 \mathrm{a}$ & $2261.5 \mathrm{a}$ & $512.6 \mathrm{a}$ & $22.7 \mathrm{a}$ \\
\hline
\end{tabular}

*Means having similar letters in the same column are not statistically differed at $\mathrm{P} \geq 0.05$.

Table 3. Effect of nanoparticles on leaf anatomical characteristics of zucchini squash cv. Rosena

\begin{tabular}{|c|c|c|c|c|c|c|}
\hline Treatments & $\begin{array}{c}\text { Leaf } \\
\text { thickness } \\
\quad(\mu \mathrm{m})\end{array}$ & $\begin{array}{c}\text { Palisade } \\
\text { length }(\mu \mathrm{m})\end{array}$ & $\begin{array}{c}\text { Sponge } \\
\text { length }(\mu \mathrm{m})\end{array}$ & $\begin{array}{c}\text { Upper } \\
\text { epidermis } \\
\text { thickness } \\
(\mu \mathrm{m})\end{array}$ & $\begin{array}{c}\text { Lower } \\
\text { epidermis } \\
\text { thickness } \\
(\mu \mathrm{m})\end{array}$ & $\begin{array}{c}\text { Area } \\
\text { space } \\
(\%)\end{array}$ \\
\hline Control $-\mathbf{T}_{\mathbf{1}}$ & $227.7 \mathrm{~d}$ & Malformed & Malformed & $10.9 \mathrm{c}$ & $10.8 \mathrm{c}$ & $2.75 \mathrm{e}$ \\
\hline $\mathrm{Cu}_{2}(\mathrm{OH})_{3} \mathrm{Cl}-\mathbf{T}_{2}$ & $257.3 \mathrm{c}$ & $102.1 \mathrm{f}$ & $129.7 \mathrm{c}$ & $10.9 \mathrm{c}$ & $14.6 \mathrm{ab}$ & $5.19 \mathrm{~d}$ \\
\hline $\mathrm{SiO}_{2} 25 \mathrm{ppm} \mathbf{T}_{\mathbf{3}}$ & $284.0 \mathrm{~b}$ & $104.2 \mathrm{f}$ & $148.7 \mathrm{~b}$ & $16.4 \mathrm{~b}$ & $14.8 \mathrm{ab}$ & $5.95 \mathrm{c}$ \\
\hline $\mathrm{SiO}_{2} 50 \mathrm{ppm} \mathbf{T}_{4}$ & $288.3 \mathrm{~b}$ & 106.4 ef & $151.5 \mathrm{~b}$ & $16.2 \mathrm{~b}$ & $14.3 \mathrm{ab}$ & $6.06 \mathrm{c}$ \\
\hline $\mathrm{TiO}_{2} 25 \mathrm{ppm} \mathbf{T}_{\mathbf{5}}$ & $312.0 \mathrm{a}$ & $124.4 \mathrm{~b}$ & $154.9 \mathrm{~b}$ & $16.8 \mathrm{~b}$ & $15.8 \mathrm{a}$ & $7.04 \mathrm{~b}$ \\
\hline $\mathrm{TiO}_{2} 50 \mathrm{ppm} \mathbf{T}_{6}$ & $318.3 \mathrm{a}$ & $136.9 \mathrm{a}$ & $148.3 \mathrm{~b}$ & $17.8 \mathrm{a}$ & $15.9 \mathrm{a}$ & $8.72 \mathrm{a}$ \\
\hline $\mathrm{SiO}_{2} 25 \mathrm{ppm}+\mathrm{TiO}_{2} 25 \mathrm{ppm} \mathbf{T}_{7}$ & $315.0 \mathrm{a}$ & $110.7 \mathrm{de}$ & $173.0 \mathrm{a}$ & $16.6 \mathrm{~b}$ & $14.6 \mathrm{ab}$ & $6.92 \mathrm{~b}$ \\
\hline $\mathrm{SiO}_{2} 25 \mathrm{ppm}+\mathrm{TiO}_{2} 50 \mathrm{ppm} \mathbf{T}_{\mathbf{8}}$ & $325.0 \mathrm{a}$ & $112.0 \mathrm{~d}$ & $180.5 \mathrm{a}$ & $17.4 \mathrm{a}$ & $15.2 \mathrm{a}$ & $7.22 \mathrm{~b}$ \\
\hline $\mathrm{SiO}_{2} 50 \mathrm{ppm}+\mathrm{TiO}_{2} 25 \mathrm{ppm} \mathbf{T}_{9}$ & $323.7 \mathrm{a}$ & $117.7 \mathrm{~cd}$ & $175.5 \mathrm{a}$ & $16.9 \mathrm{~b}$ & $13.6 \mathrm{~b}$ & $7.02 \mathrm{~b}$ \\
\hline $\mathrm{SiO}_{2} 50 \mathrm{ppm}+\mathrm{TiO}_{2} 50 \mathrm{ppm} \mathbf{T}_{10}$ & $327.0 \mathrm{a}$ & $118.3 \mathrm{c}$ & $176.1 \mathrm{a}$ & $17.0 \mathrm{ab}$ & $15.7 \mathrm{a}$ & $7.04 \mathrm{~b}$ \\
\hline
\end{tabular}

*Means having similar letters in the same column are not statistically differed at $\mathrm{P} \geq 0.05$. 

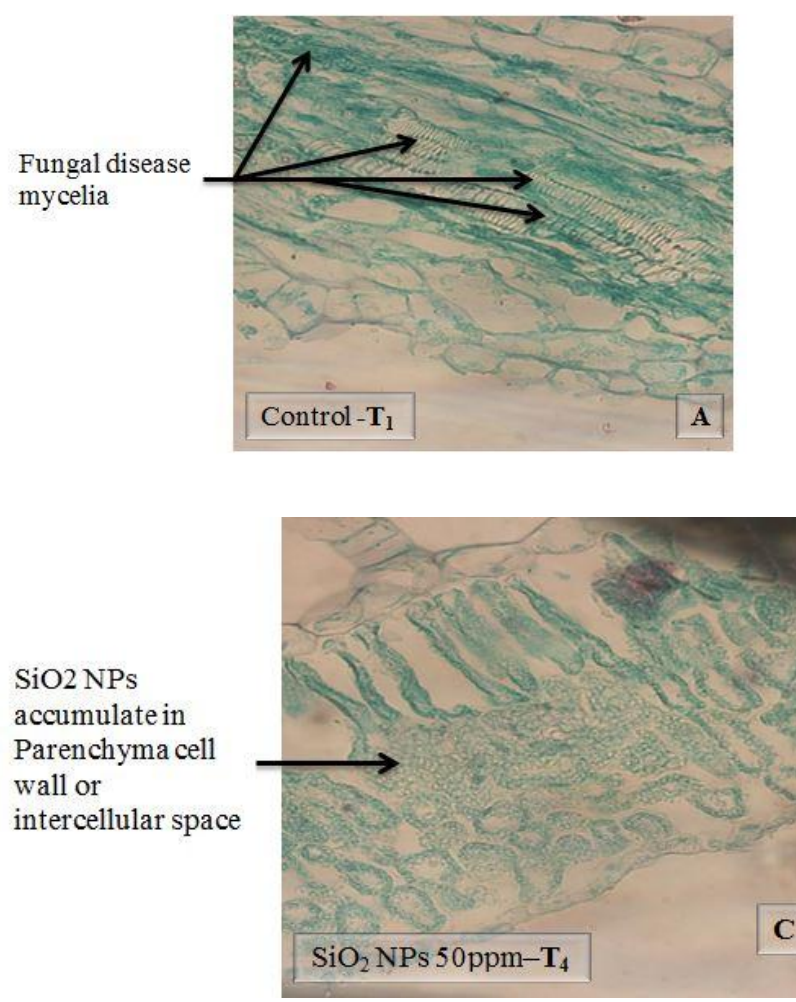
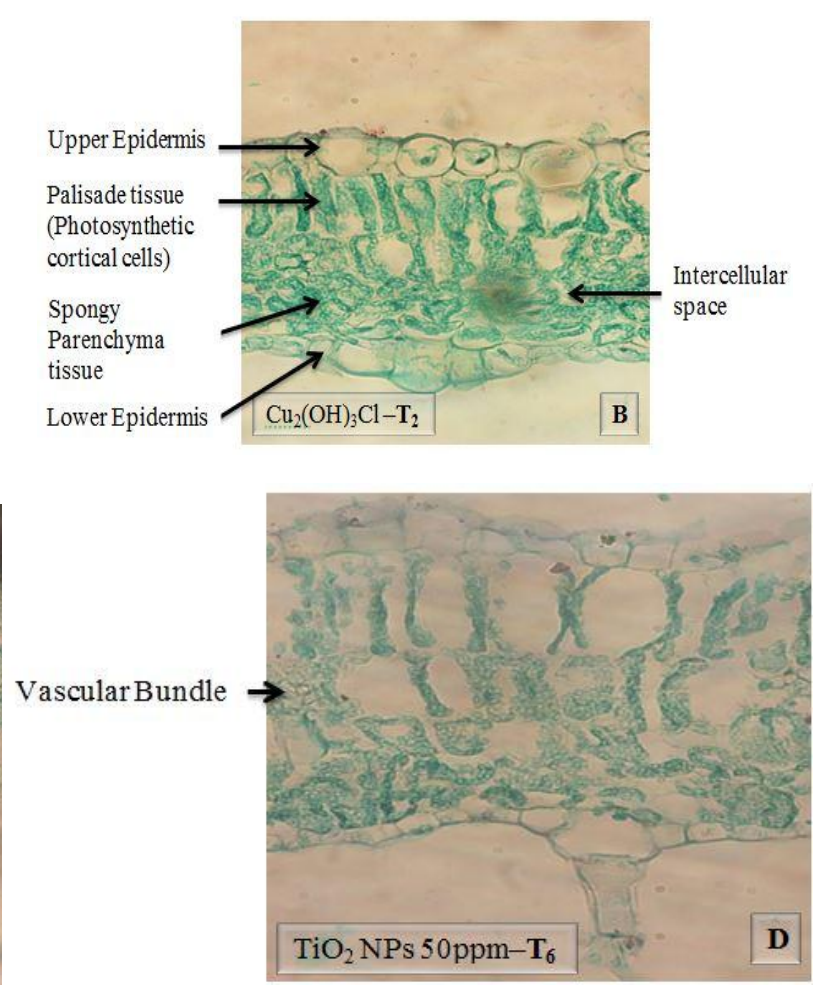

Figure 1. Photomicroscope of zucchini squash leaf cross section at 75 days old treated with: (A) control sprayed with distilled water $52 \times(\mathrm{B}) \mathrm{Cu}_{2}(\mathrm{OH})_{3} \mathrm{Cl} 40 \mathrm{x}(\mathrm{C}) \mathrm{SiO}_{2} \mathrm{NPs}$ at concentration of $50 \mathrm{ppm}$ 40x (D) $\mathrm{TiO}_{2}$ NPs at concentration of $50 \mathrm{ppm}$ 40x

\section{C.Yield and its components:}

Regarding, data related to the influence NPs of $\mathrm{SiO}_{2}$ and $\mathrm{TiO}_{2}$ on zucchini squash quality which expressed as number of fruits plant ${ }^{-1}$, fresh and dry fruit weight, fruit dry matter \%, number and weight of un-marketing fruit plant $^{-1}$ and for plot $^{-1}$ were presented in Table 4. Data cleared that significant increases were recorded in all late recently mentioned parameters when NPs are tested. The treatments increased number of fruits plant ${ }^{-1}$ when compared with control. The highest values were associated with tested treatments except $\mathrm{TiO}_{2}$. Also, tested materials increased fresh and dry fruit weight and fruit dry matter percentage when compared with control while the highest values were attained by $\mathrm{T}_{10}, \mathrm{~T}_{8}, \mathrm{~T}_{6}, \mathrm{~T}_{5}$, $\mathrm{T}_{9}$ and $\mathrm{T}_{7}$ respectively. Control treatment and $\mathrm{TiO}_{2} \mathrm{NPs}$ in low or high concentration whether individual or in combination with $\mathrm{SiO}_{2} \mathrm{NPs}$ significantly produced the highest heavy un-marketable fruit weight for plant and plot while the lowest weights were achieved of foliar sprayed with both concentration of $\mathrm{SiO}_{2} \mathrm{NPs}$. Also data cleared that high significant increases of un-marketable fruits number had been gotten from control treatment and the minimum values were attained from sprayed $\mathrm{SiO}_{2}$ NPs. Also, data presented in Table 5 indicated that all treatments include $\mathrm{Cu}_{2}(\mathrm{OH})_{3} \mathrm{Cl}$ led to significantly increased yield whether per plant, plot or feddan as well as marketable yield when compared with control treatment. The maximum increases of total yield per feddan were attained in sequence from $\mathrm{T}_{10}, \mathrm{~T}_{2}, \mathrm{~T}_{9}, \mathrm{~T}_{8}$, $\mathrm{T}_{7}, \mathrm{~T}_{4}$ and $\mathrm{T}_{3}$ treatments. While the maximum increase of marketable yield were achieved from $\mathrm{T}_{10}, \mathrm{~T}_{2}, \mathrm{~T}_{4}, \mathrm{~T}_{9}$, $\mathrm{T}_{8}, \quad \mathrm{~T}_{7}$ and $\mathrm{T}_{3}$ treatments compared with control treatment. Total and marketable yield per feddan increases when compared with control treatment were 120.4 and $143.2 \%$ respectively when plants treated with $\mathrm{SiO}_{2} 50 \mathrm{ppm}+\mathrm{TiO}_{2} 50 \mathrm{ppm}$, while the $\mathrm{Cu}_{2}(\mathrm{OH})_{3} \mathrm{Cl}$ spraying increased them 119.3 and $141.3 \%$ respectively. On other hand, the highest un-marketable yield was achieved from treatment $\mathrm{T}_{8}, \mathrm{~T}_{9}, \mathrm{~T}_{1}, \mathrm{~T}_{5}, \mathrm{~T}_{6}$ and $\mathrm{T}_{7}$. The minimum un-marketable yield was 780 $\mathrm{kg} /$ feddan achieved from $\mathrm{SiO}_{2} \mathrm{NPs}$ at concentration 50 ppm. These finding agree with Hong et al., (2005), Yang et al., (2006), Jaberzadeh et al. (2013) and Karunakaran et al. (2013) who reported that $\mathrm{TiO}_{2} \mathrm{NPs}$ and $\mathrm{SiO}_{2} \mathrm{NPs}$ at low concentration $(0.02 \%)$ individual or in mixture increased dry matter $(\%)$ in spinach and some hydrolytic and antioxidant enzymes activity in germination and seedling phases of onion, also, seed 
number and 1000-seed weight, final yield, biomass, harvest index, gluten, and starch contents of wheat. These results are reflect that $\mathrm{TiO}_{2}$ NPs can enhancing growth and increase plant weight through promoting plants absorb more essential nutrient elements (as shown in Table 6). In addition, there were no complex components like protein, carbohydrates, fats, hormones, enzymes, vitamins ..... etc. were formed without promote producing some plant hydrolytic enzymes such as amylase and protease (Laware and Raskar, 2014 and Shallan et al.,2016) which analyses starch and protein to more simple components in turn were plants more sensitive for diseases. On the other hand, $\mathrm{SiO}_{2} \mathrm{NPs}$ can resist plant diseases through particles accumulation within or between cells or as part of the cell wall in the case of the leaf epidermis as biogenic opal as postulated in Figure 1 and Table 3, (Sangster, et. al., 2001 and Canny, 2006). For the above, the combination of NPs $\mathrm{TiO}_{2}$ and $\mathrm{SiO}_{2}$ can produce healthy plants and improve growth and productivity.

\section{Chemical composition:}

Data related to assayed chemical components of zucchini squash effected by recommended practices and NPs of $\mathrm{SiO}_{2}$ or / and $\mathrm{TiO}_{2}$ were scheduled in Table 6 . Chlorophyll content significantly increased with all treatments which were tested compared with control treatment; the highest increase $35.5 \%$ more than control) was achieved from NPs mixture sprayed at high concentration $\left(\mathrm{T}_{10}\right)$, while the lowest increase $(16.9 \%$ more than control) had been gotten from $\mathrm{T}_{2}$.
Nitrogen and potassium accumulation in squash leaves significantly increased with $\mathrm{TiO}_{2}$ NPs at tested concentrations separate or in combination with low and high concentrations of $\mathrm{SiO}_{2}$ NPs. The maximum of nitrogen and potassium accumulations were associated with treatments of $\mathrm{T}_{10}, \mathrm{~T}_{8}, \mathrm{~T}_{9}, \mathrm{~T}_{7}, \mathrm{~T}_{6}$ and $\mathrm{T}_{5}$. On other side, no significant differences were found between $\mathrm{SiO}_{2}$ NPs at low concentration. and $\mathrm{Cu}_{2}(\mathrm{OH})_{3} \mathrm{Cl}$ or control treatments.

Regarding to the tested treatments impact on $\mathrm{P}_{2} \mathrm{O}_{5}{ }^{--}$ accumulate in zucchini squash leaves, data cleared that NPs treatments significantly increased $\mathrm{P}_{2} \mathrm{O}_{5}{ }^{--}$compared with $\mathrm{T}_{1}$ and $\mathrm{T}_{2}$ (Table 6). The highest values of $\mathrm{P}_{2} \mathrm{O}_{5}^{--}$ were attained from $\mathrm{T}_{10}, \mathrm{~T}_{8}, \mathrm{~T}_{9}$ and $\mathrm{T}_{7}$. These results agree with Hong et al., (2005), Yang et al. (2006) and Laware and Raskar, (2014) who reported that $\mathrm{TiO}_{2} \mathrm{NPs}$ at low concentrations (10-30 ppm) increased photosynthesis pigments, nitrogen metabolism and photosynthetic rate in Spinach, increased stimulates ribulose 1, 5-bisphosphate carboxylase activity, hydrolytic and antioxidant enzymes activity in germination and seedling phases. The present results postulated that the nano size of $\mathrm{TiO}_{2}$ may have increased the absorption of inorganic nutrients, accelerated the breakdown of organic substances, and also caused quenching of oxygen free radicals formed during the photosynthetic process, hence increasing the photosynthetic rate (Zheng et al., 2005 and Shallan et al.,2016).

Table 4. Effect of nanoparticles on fruit quality of zucchini squash $c v$. Rosena

\begin{tabular}{|c|c|c|c|c|c|c|c|}
\hline \multirow[b]{2}{*}{ Treatments } & \multirow{2}{*}{$\begin{array}{l}\text { No. } \\
\text { fruits } \\
\text { /plant }\end{array}$} & \multicolumn{2}{|c|}{ Fruit weight $g$} & \multirow{2}{*}{$\begin{array}{c}\text { Fruit } \\
\text { dry } \\
\text { matter } \\
\%\end{array}$} & \multicolumn{3}{|c|}{ Un marketable fruit } \\
\hline & & Fresh & Dry & & $\begin{array}{l}\text { No. I } \\
\text { plant }\end{array}$ & $\begin{array}{l}\text { Weight } \\
\text { g/plant }\end{array}$ & $\begin{array}{l}\text { Weight } \\
\text { kg/plot }\end{array}$ \\
\hline Mean \pm SD & $9.5 \pm 0.4$ & $142.5 \pm 3.8$ & $17.2 \pm 1.3$ & $12.0 \pm 0.8$ & $0.60 \pm 0.06$ & $85.3 \pm 9.1$ & $2.56 \pm 0.27$ \\
\hline Control $-\mathbf{T}_{\mathbf{1}}$ & $5.3 \mathrm{c}$ & $128.2 \mathrm{~d}$ & $15.6 \mathrm{~cd}$ & $12.13 \mathrm{abc}$ & $0.74 \mathrm{a}$ & $94.3 \mathrm{a}$ & $2.83 \mathrm{a}$ \\
\hline $\mathrm{Cu}_{2}(\mathrm{OH})_{3} \mathrm{Cl}-\mathbf{T}_{2}$ & $10.4 \mathrm{a}$ & $142.1 \mathrm{bc}$ & $14.9 \mathrm{~d}$ & $10.47 \mathrm{~d}$ & $0.57 \mathrm{~cd}$ & $81.3 \mathrm{bc}$ & $2.44 \mathrm{~b}$ \\
\hline $\mathrm{SiO}_{2} 25 \mathrm{ppm} \mathbf{T}_{\mathbf{3}}$ & $10.2 \mathrm{a}$ & $140.9 \mathrm{c}$ & $15.9 \mathrm{~cd}$ & $11.27 \mathrm{~cd}$ & $0.52 \mathrm{de}$ & $73.3 \mathrm{~cd}$ & $2.20 \mathrm{bc}$ \\
\hline $\mathrm{SiO}_{2} 50 \mathrm{ppm} \mathbf{T}_{4}$ & $10.1 \mathrm{a}$ & $143.0 \mathrm{abc}$ & $16.7 \mathrm{bc}$ & $11.67 \mathrm{bc}$ & $0.45 \mathrm{e}$ & $65.1 \mathrm{~d}$ & $1.95 \mathrm{c}$ \\
\hline $\mathrm{TiO}_{2} 25 \mathrm{ppm} \mathbf{T}_{\mathbf{5}}$ & $9.1 \mathrm{~b}$ & $145.4 \mathrm{ab}$ & $17.6 \mathrm{ab}$ & $12.10 \mathrm{abc}$ & $0.63 \mathrm{bc}$ & $91.0 \mathrm{ab}$ & $2.73 \mathrm{ab}$ \\
\hline $\mathrm{TiO}_{2} 50 \mathrm{ppm} \mathbf{T}_{6}$ & $9.5 \mathrm{~b}$ & $146.3 \mathrm{ab}$ & $18.3 \mathrm{a}$ & $12.53 \mathrm{ab}$ & $0.61 \mathrm{bc}$ & $89.0 \mathrm{ab}$ & $2.67 \mathrm{ab}$ \\
\hline $\mathrm{SiO}_{2} 25 \mathrm{ppm}+\mathrm{TiO}_{2} 25 \mathrm{ppm} \mathbf{T}_{7}$ & $10.2 \mathrm{a}$ & $143.2 \mathrm{abc}$ & $17.7 \mathrm{ab}$ & $12.33 \mathrm{ab}$ & $0.62 \mathrm{bc}$ & $88.8 \mathrm{ab}$ & $2.66 \mathrm{ab}$ \\
\hline $\mathrm{SiO}_{2} 25 \mathrm{ppm}+\mathrm{TiO}_{2} 50 \mathrm{ppm} \mathbf{T} 8$ & $10.0 \mathrm{a}$ & $146.0 \mathrm{ab}$ & $18.4 \mathrm{a}$ & $12.57 \mathrm{ab}$ & $0.67 \mathrm{~b}$ & $97.3 \mathrm{a}$ & $2.92 \mathrm{a}$ \\
\hline $\mathrm{SiO}_{2} 50 \mathrm{ppm}+\mathrm{TiO}_{2} 25 \mathrm{ppm} \mathbf{T}_{9}$ & $10.3 \mathrm{a}$ & $143.3 \mathrm{abc}$ & $17.6 \mathrm{ab}$ & $12.27 \mathrm{ab}$ & $0.67 \mathrm{~b}$ & $95.9 \mathrm{a}$ & $2.88 \mathrm{a}$ \\
\hline $\mathrm{SiO}_{2} 50 \mathrm{ppm}+\mathrm{TiO}_{2} 50 \mathrm{ppm} \mathbf{T}_{\mathbf{1 0}}$ & $10.1 \mathrm{a}$ & $146.7 \mathrm{a}$ & $19.0 \mathrm{a}$ & $12.97 \mathrm{a}$ & 0.53 & $77.2 \mathrm{c}$ & $2.32 \mathrm{~b}$ \\
\hline
\end{tabular}

*Means having similar letters in the same column are not statistically differed at $\mathrm{P} \geq 0.05$. 
Table 5. Effect of nanoparticles on yield of zucchini squash $c v$. Rosena

\begin{tabular}{|c|c|c|c|c|c|}
\hline \multirow{2}{*}{ Treatments } & \multicolumn{2}{|c|}{$\begin{array}{c}\text { Average of fruit yield } \\
\text { kg }\end{array}$} & \multirow{2}{*}{$\begin{array}{l}\text { Total of } \\
\text { fruit yield } \\
\text { ton/fed. }\end{array}$} & \multirow{2}{*}{$\begin{array}{c}\text { Un } \\
\text { marketable } \\
\text { fruit ton/fed. }\end{array}$} & \multirow{2}{*}{$\begin{array}{r}\text { Marketable } \\
\text { yield ton/fed }\end{array}$} \\
\hline & Plant $^{-1}$ & Plot $^{-1}$ & & & \\
\hline Mean \pm SD & $1.36 \pm 0.06$ & $40.9 \pm 1.8$ & $16.35 \pm 0.72$ & $1.02 \pm 0.11$ & $15.32 \pm 0.76$ \\
\hline Control $-\mathbf{T}_{\mathbf{1}}$ & $0.67 \mathrm{~d}$ & $20.22 d$ & $8.09 \mathrm{~d}$ & $1.13 \mathrm{a}$ & $6.95 \mathrm{~d}$ \\
\hline $\mathrm{Cu}_{2}(\mathrm{OH})_{3} \mathrm{Cl}-\mathbf{T}_{2}$ & $1.48 \mathrm{a}$ & $44.36 \mathrm{a}$ & $17.74 \mathrm{a}$ & $0.98 \mathrm{bc}$ & $16.77 \mathrm{a}$ \\
\hline $\mathrm{SiO}_{2} 25 \mathrm{ppm} \mathbf{T}_{3}$ & $1.44 \mathrm{ab}$ & $43.13 \mathrm{ab}$ & $17.25 \mathrm{ab}$ & $0.88 \mathrm{~cd}$ & $16.37 \mathrm{a}$ \\
\hline $\mathrm{SiO}_{2} 50 \mathrm{ppm} \mathbf{T}_{4}$ & $1.45 \mathrm{ab}$ & $43.38 \mathrm{ab}$ & $17.35 \mathrm{ab}$ & $0.78 \mathrm{~d}$ & $16.57 \mathrm{a}$ \\
\hline $\mathrm{TiO}_{2} 25 \mathrm{ppm} \mathbf{T}_{\mathbf{5}}$ & $1.32 \mathrm{c}$ & $39.55 \mathrm{c}$ & $15.82 \mathrm{c}$ & $1.09 \mathrm{ab}$ & $14.73 \mathrm{c}$ \\
\hline $\mathrm{TiO}_{2} 50 \mathrm{ppm} \mathbf{T}_{6}$ & $1.39 \mathrm{~b}$ & $41.73 b$ & $16.69 b$ & $1.07 \mathrm{ab}$ & $15.62 \mathrm{~b}$ \\
\hline $\mathrm{SiO}_{2} 25 \mathrm{ppm}+\mathrm{TiO}_{2} 25 \mathrm{ppm} \mathbf{T}_{7}$ & $1.46 \mathrm{a}$ & $43.67 \mathrm{ab}$ & $17.47 \mathrm{ab}$ & $1.07 \mathrm{ab}$ & $16.40 \mathrm{a}$ \\
\hline $\mathrm{SiO}_{2} 25 \mathrm{ppm}+\mathrm{TiO}_{2} 50 \mathrm{ppm} \mathbf{T}_{\mathbf{8}}$ & $1.46 \mathrm{a}$ & $43.94 \mathrm{a}$ & $17.58 \mathrm{a}$ & $1.17 \mathrm{a}$ & $16.41 \mathrm{a}$ \\
\hline $\mathrm{SiO}_{2} 50 \mathrm{ppm}+\mathrm{TiO}_{2} 25 \mathrm{ppm} \mathbf{T} \mathbf{9}$ & $1.47 \mathrm{a}$ & $44.24 \mathrm{a}$ & $17.70 \mathrm{a}$ & $1.15 \mathrm{a}$ & $16.55 \mathrm{a}$ \\
\hline $\mathrm{SiO}_{2} 50 \mathrm{ppm}+\mathrm{TiO}_{2} 50 \mathrm{ppm} \mathbf{T}_{\mathbf{1 0}}$ & $1.49 \mathrm{a}$ & $44.57 \mathrm{a}$ & $17.83 \mathrm{a}$ & $0.93 \mathrm{c}$ & $16.90 \mathrm{a}$ \\
\hline
\end{tabular}

* Means having similar letters in the same column are not statistically differed at $\mathrm{P} \geq 0.05$.

Table 6. Effect of nanoparticles on chemical composition of zucchini squash $c v$. Rosena

\begin{tabular}{|c|c|c|c|c|}
\hline \multirow{2}{*}{$\begin{array}{ll}\text { Treatments } & \text { parameters } \\
\text { Then }\end{array}$} & \multirow{2}{*}{$\begin{array}{l}\text { Chlorophyll } \\
\text { content }\end{array}$} & \multicolumn{3}{|c|}{$\operatorname{mg}(\mathrm{g} \mathrm{DW})^{-1}$} \\
\hline & & $\mathrm{NO}_{3}^{-}$ & $\mathbf{P}_{2} \mathrm{O}_{5}^{--}$ & $\mathbf{K}^{+}$ \\
\hline Mean \pm SD & $50.94 \pm 3.44$ & $22.76 \pm 0.54$ & $2.51 \pm 0.05$ & $33.33 \pm 0.71$ \\
\hline Control $-\mathbf{T}_{\mathbf{1}}$ & $41.57 \mathrm{f}$ & $21.63 \mathrm{e}$ & $2.39 \mathrm{e}$ & $31.84 \mathrm{e}$ \\
\hline $\mathrm{Cu}_{2}(\mathrm{OH})_{3} \mathrm{Cl}-\mathbf{T}_{2}$ & $48.63 \mathrm{e}$ & $21.77 \mathrm{e}$ & $2.41 \mathrm{e}$ & $32.02 \mathrm{de}$ \\
\hline $\mathrm{SiO}_{2} 25 \mathrm{ppm} \mathbf{T}_{\mathbf{3}}$ & $49.60 \mathrm{de}$ & $22.19 \mathrm{de}$ & $2.45 \mathrm{~cd}$ & $32.55 \mathrm{de}$ \\
\hline $\mathrm{SiO}_{2} 50 \mathrm{ppm} \mathbf{T}_{4}$ & 50.67 cde & $22.85 b c$ & $2.47 \mathrm{c}$ & $32.90 \mathrm{bcd}$ \\
\hline $\mathrm{TiO}_{2} 25 \mathrm{ppm} \mathbf{T}_{\mathbf{5}}$ & 49.77 cde & $23.04 \mathrm{abc}$ & $2.52 \mathrm{~b}$ & $33.45 \mathrm{abc}$ \\
\hline $\mathrm{TiO}_{2} 50 \mathrm{ppm} \mathbf{T}_{\mathbf{6}}$ & 50.70 cde & $23.18 \mathrm{ab}$ & $2.55 \mathrm{~b}$ & $33.89 \mathrm{abc}$ \\
\hline $\mathrm{SiO}_{2} 25 \mathrm{ppm}+\mathrm{TiO}_{2} 25 \mathrm{ppm} \mathbf{T}_{7}$ & $52.73 \mathrm{bcd}$ & $23.30 \mathrm{ab}$ & $2.56 \mathrm{ab}$ & $34.04 \mathrm{abc}$ \\
\hline $\mathrm{SiO}_{2} 25 \mathrm{ppm}+\mathrm{TiO}_{2} 50 \mathrm{ppm} \mathbf{T}_{\mathbf{8}}$ & $53.33 \mathrm{abc}$ & $23.40 \mathrm{ab}$ & $2.57 \mathrm{ab}$ & $34.17 \mathrm{ab}$ \\
\hline $\mathrm{SiO}_{2} 50 \mathrm{ppm}+\mathrm{TiO}_{2} 25 \mathrm{ppm} \mathbf{T} \mathbf{9}$ & $56.03 \mathrm{ab}$ & $23.30 \mathrm{ab}$ & $2.56 \mathrm{ab}$ & $34.04 \mathrm{ab}$ \\
\hline $\mathrm{SiO}_{2} 50 \mathrm{ppm}+\mathrm{TiO}_{2} 50 \mathrm{ppm} \mathbf{T}_{\mathbf{1 0}}$ & $56.33 \mathrm{a}$ & $23.57 \mathrm{a}$ & $2.59 \mathrm{a}$ & $34.39 \mathrm{a}$ \\
\hline
\end{tabular}

*Means having similar letters in the same column are not statistically differed at $\mathrm{P} \geq 0.05$.

\section{REFERENCES}

Ali,M. , B. Kim, K.D. Belfield, D. Norman, M. Brennan and G.S. Ali. 2015. Inhibition of Phytophthora parasitica and $P$. capsici by silver nanoparticles synthesized using aqueous extract of Artemisia absinthium. Phytopathology 105:1183-1190.

Ball P. 2002. Natural strategies for the molecular engineer. Nanotechnology. 13: 15-28.

Brown, J. D and O. Lilliland. 1964 Rapid determination of potassium and sodium in plant material and soil extracts flow phosphorus. Proc. Amer. Soc. Hort. Sci. 48: 341346.

Canny, M.J. 2006. What becomes of the transpiration stream?. New Phytol. 114: 341-368.

Dehkourdi E.H. and M. Mosavi. 2013. Effect of anatase nanoparticles (TiO2) on parsley seed germination (Petroselinum crispum) in vitro. Biol. Trace Elem. Res. 155(2):283-286.
Elsharkawy M.M., G.A.N. El-Kot and M. Hegazi. 2015. Management of rose powdery mildew by nanosilica, diatomite and bentocide. Egy. J. Bio. Pest Cont.25 (3): 545-553.

Farhat, M. G., W. M. Haggag, M. S. Thabet and A. A. Mosa. 2018.Efficacy of silicon and titanium nanoparticles biosynthesis by some antagonistic fungi and bacteria for controlling powdery mildew disease of wheat plants. Int. J. Agric. Technol. 14(5): 661-674.

Fauteux, F., W. Rémus-Borel, J.G. Menzies and R.R. Bélanger. 2005. Silicon and plant disease resistance against pathogenic fungi. FEMS Microbiol. Lett. 249:1-6.

Feizi H., M. Kamali, L. Jafari and P. Rezvani Moghaddam. 2013. Phytotoxicity and stimulatory impacts of nanosized and bulk titanium dioxide on fennel (Foeniculum vulgare Mill.). Chemosphere.91(4): 506-511.

Frie, E., K. Peyer and E. Schultz1. 1964. Determination of phosphorus by ascorbic acid. Schw. Land. Wirt Schaft for shung Heft. 3: 318- 328. 
Guével, M.H., J.G. Menzies and E.E. Bélanger. 2007. Effect of root and foliar applications of soluble silicon on powdery mildew control and growth of wheat plants. Eur. J. Plant Pathol. 119: 429-436.

Hong F., J. Zhou, C. Liu, F. Yang, C. Wu, L. Zheng and P.Yang. 2005. Effect of nano-TiO2 on photochemical reaction of chloroplasts of spinach. Biol Trace Elem Res. 105: 269-279.

Jaberzadeh A, P. Moaveni, H. R.T. Moghadam and H. Zahedi. 2013. Influence of bulk and nanoparticles titanium foliar application on some agronomic traits, seed gluten and starch contents of wheat subjected to water deficit stress. Not Bot Horti Agrobo. 41(1):201-207

Jackson M.E. 1962. Soil chemical analysis. Constable and Company E td. 448pp.

Janmohammadi, M., T. Amanzadeh, N. Sabaghnia and V. Ion. 2016. Effect of nano-silicon foliar application on safflower growth under organic and inorganic fertilizer regimes. Bot. Lith. 22:53-64.

Jiang F., Y. Shen, C. Ma, X. Zhang, W. Cao and Y. Rui. 2017. Effects of $\mathrm{TiO}_{2}$ nanoparticles on wheat (Triticum aestivum L.) seedlings cultivated under super-elevated and normal $\mathrm{CO}_{2}$ conditions. PLoS ONE 12(5):1-14 https://doi.org/10.1371/journal.pone.0178088

Johansen, D.A., 1940. Plant microtechnquie Mc. Gow Hill Book Company. London.pp: 523.

Karunakaran G., R. Suriyaprabha, P. Manivasakan, R. Yuvakkumar, V. Rajendran, P. Prabu and N. Kannan. 2013. Effect of nanosilica and silicon sources on plant growth promoting rhizobacteria, soil nutrients and maize seed germination. IET Nanobiotechnology . 7( 3): 70 - 77.

Kim, S. G.; K. W. Kim; E. W. Park and D. Choi (2002). Silicon-induced cell wall fortification of rice leaves: A possible cellular mechanism of enhanced host resistance to blast. Phytopathology, 92:1095-1103.

Laane H. M. 2018. The effects of foliar sprays with different silicon compounds. plants, 7(2):45pp

Laware S.L. and S. Raskar. 2014. Effect of titanium dioxide nanoparticles on hydrolytic and antioxidant enzymes during seed germination in onion. Int.J.Curr.Microbiol.App.Sci. 3(7): 749-760.

Lu C. M., C. M. Zhang, J. Q. Wen , G.R. Wu and M.X. Tao.2002. Research of the effect of nanometer materials on germination and growth enhancement of Glycine max and its mechanism. Soybean Sci. 21:168-172.

Ma, J.F., A. Higashitani, K. Sato and K. Tateda. 2003. Genotypic variation in $\mathrm{Si}$ content of barley grain. Plant Soil. 249: 383-387.

McGrath, M.T., H. Staniszewska and N. Shishko. 1996. Fungicide sensitivity of phaerotheca fuliginea populations in the United States. Plant Dis. 80:697-703.

Peach, K. and M. R. Tracey.1959. Modern methods of plant analysis. Vol. 1 Springer Verlage, Berlin. 4:643.

Piper, SC.S. 1950. Soil and plant analysis. Univ. Inter Sci. publishers. Inc. New york. Adelaide:258-275.
Rangaraj S., G. Karunakaran, K. Kavitha, R. yuvakkumar, V. Rajendran and N. Kannan. 2014. Application of silica nanoparticles in maize to enhance fungal resistance. IET Nanobiotechnol. 8(3): 133-137.

Richards, L.A. 1954. Diagnosis and improvement of saline and alkaline soils. Agric. Hand Book. No.60. U.S.A

Russell, D. F. 1991. In MSTATC, Directory crop soil science Department Michigan Universty.USA.

Sangster, A.G., M.J. Hodson and H.J. Tubb. 2001. Silicon deposition in higher plants. In Silicon in Agriculture; Elsevier: Amsterdam. The Netherlands: 85-114 pp.

Shallan M. A., H. M.M. Hassan, A. A.M. Namich and A. A. Ibrahim. 2016.Biochemical and physiological effects of $\mathrm{TiO} 2$ and $\mathrm{SiO} 2$ nanoparticles on cotton plant under drought stress. Res. J. Pharmac., Bio. and Chemic. Sci. 7(4):1540-1553.

Shwethakumari, U. 2017. Effect of foliar application of silicic acid on growth, yield and quality of soybean [Glycine max. (L)]. In Proceedings of the 7th International Conference on Silicon in Argriculture. Bengaluru. India. 24-28:p. 146.

Siddiqui M. H., M. H. Al-Whaibi, M. Firoz and M. Y. AlKhaishany. 2015. Nanotechnology and Plant Sciences. Springer International Publishing Switzerland. DOI 10.1007/978-3-319-14502-0_2.

Singh, R.S. 2004.Introduction to principles of plant pathology, $4^{\text {th }} \mathrm{Ed}$, Oxford and IBH Publication, Pvt. Ltd. New Delhe (India).

Singh, D., S.C. Singh, S. Kumar,B. Lal and N.B. Singh. 2010. Effect of titanium dioxide nanoparticles on the growth and biochemical parameters of Brassica oleracea. In: Riberio, C. de-Assis. O.B.G. Mattoso, L.H.C., Mascarenas, S. (Eds.), Symposium of International Conference on Food and Agricultural Applications of Nanotechnologies. São Pedro. SP. Brazil. ISBN 978-85-63274-02-4.

Suriyaprabha, R., G. Karunakaran, R. Yuvakkumar, V. Rajendran and N. Kannan. 2014. Foliar application of silica nanoparticles on the phytochemical responses of Maize (Zea mays L.) and its toxicological behavior. Synth. React. Inorg. Metal.Org. Nano.Met. Chem. 44: 11281131.

Takahashi E., J.F. Ma and Y. Miyake. 1990. The possibility of silicon as an essential element for higher plants. Comments Agric. Food Chem. 2: 99-102.

Tacchini I., E. Terrado, A. Anso'n and M.T. Martı'nez. 2011. Preparation of a $\mathrm{TiO}_{2} \quad-\mathrm{MoS}_{2}$ nanoparticle-based composite by solvothermal method with enhanced photoactivity for the degradation of organic molecules in water under UV light. Micro \& Nano Letters. 6 (11):932936.

Wolff, S.A., I. Karoliussen, J. Rohloff and R. Strimbeck. 2012.Foliar application of silicon fertilizers inhibit powdery mildew in greenhouse cucumber. J. Food Agric. Environ. 10: 335-359. 
Yang F., F. Hong,W. You, C. Liu , F. Gao, C. Wu and P. Yang . 2006. Influences of nano-anatase $\mathrm{TiO}_{2}$ on the nitrogen metabolism of growing spinach. Biol Trace Elem Res. 110(2):179-90.
Yassen, A., E. Abdallah,M. Gaballah and S. Zaghloul. 2017. Role of Silicon dioxide nano fertilizer in mitigating salt stress on growth, yield and chemical composition of cucumber (Cucumis sativus L.). Int. J. Agric. Res. 22:130135.

Zheng L., F. Hong, S. Lu, C. Liu. 2005. Effect of nano-TiO2 on strength of naturally aged seeds and growth of spinach. Biol. Trace Elem. Res. 104.83e91. 


\section{الملخص العربي}

دراسات مقارنه باستخدام تكنولوجيا النانو على مقاومة الامراض الفطريه لتحسين إنتاجيه محصول

\section{الكوسه}

خالد عوض الها أحمد و محمد خالد محمد رشدى أغا

الرش بالجزيئات متتاهية الصغر من أكسيد السليكون سواء

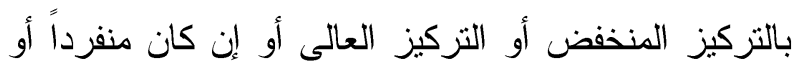
مخلوطاً بتركيزى أكسيد التيتانيوم وذلك عند الكيز التقارنه بمعاملة المقارنة (م)). لم يستجيب البياض الدقيقى لمعاملات الرش بالتيتانوم المنفرد بينما أنخفض معدل

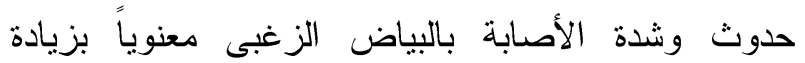

التزكيز حتى 50 جزء فى المليون مقارنة بالمعاملة (م)). أظهرت النتائج الى أن جميع معاملات الرش بالمواد التراد

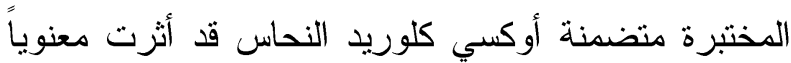

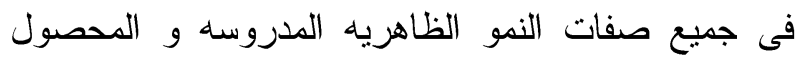
ومكوناته وكذللك المحصول القابل للتسويق بالأضافة الى صبغات التمثيل الضوئي ومحتوى النبات من النيتروجين و الفوسفور والبوتاسيوم مقارنة بالمعاملة التى أستخدم فيها

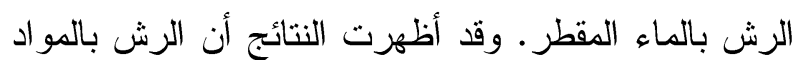

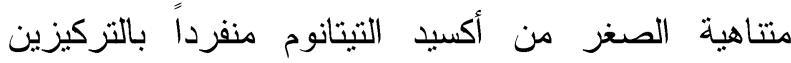

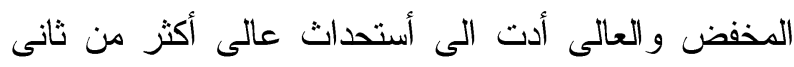

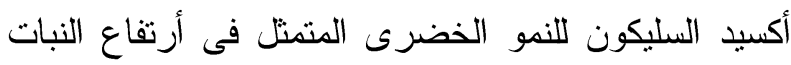
وعدد الأفرع والأوراق ومساحة الورقة وكذلك الوزن الطازج والجاف بالإضافة الى النسبة المئوية للمادة الجافة

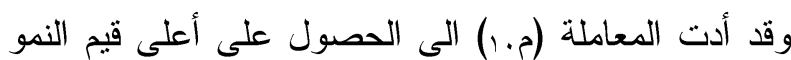
الخضرى مقارنة المعاملة (م) و (مr).

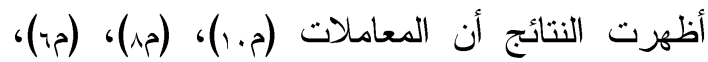

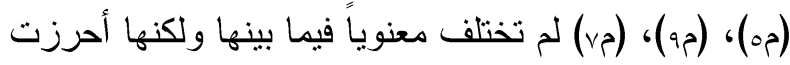
أعلى قيم الوزن الطازج والجاف الجاف والنسبة المئوية للمادة الجافة بالثمارمقارنة بالمعاملة (م) فى حين أن أعلى قيم عدد الثمار قد نتج من جميع المعاملات المختبرة ماعدا معاملات أكسيد التيتانيوم المنفردة.
أجريت هذه التجربة لدراسة مدى تأثيرتركيزات مختلفة من أكسيد السليكون و أكسيد التيتانيوم كمواد متتاهية الصغر لتركر كلاً على حدى أو مخاليطهم على مقاومة الأمر اض الفطرية وتحسين نمو و إنتاجية محصول الكوسة مقارنة بالممارسات التقليدية. وقد أجريت التجربة بمحطة بحوث القنطرة شرق بلهُ

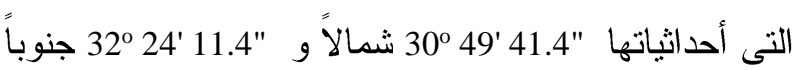
فى الجانب الثرقى من محافظة الأسماعيلية بسيناء جمهورية مصر العربية خلال صيف موسمي 10.ب و . أستخدمت المعاملات: الـ الرش بالماء المقطر للمقارنه

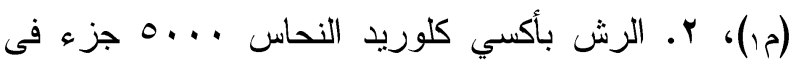
المليون للمقارنه (مr)، r. الرش بثانى أكسيد السليكون بمعدل 25 جزء فى المليون (مب)، ؛. الرش بثانى أكسيد السليكون بمعدل 50 جزء فى المليون (مء)، ه. الرش بثانى

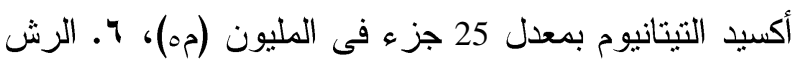
بثانى أكسيد التيتانيوم بمعدل 50 جزء فى المليون (مه)، V.

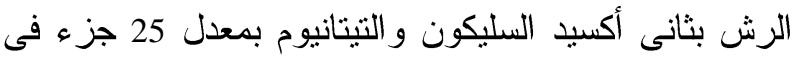

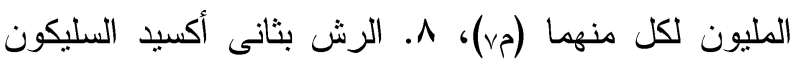
بمعدل 25 جزء فى المليون و أكسيد التيتانيوم بمعدل 50 جزء فى المليون (مه)، 9. بمعدل 50 جزء فى المليون وأكسيد التيتانيوم بمعدل 25 جزء فى المليون (مه)، • 1. الرش بثانى أكسيد السليكون بمعدل 50 جزء فى المليون و أكسيد التيتانيوم بمعدل 50 جزء فى المليون (م.ر). أظهرت النتائج الى أن معدل حدوث وشدة الأصابة بمرضى البياض الدقيقى و الزغبى إنخفضتا معنوياً عند الند 
و السفلية وكذلك النسبة المئوية لمساحة فرغات تبادل الغازات قد زادت نتيجة لمعاملة النباتات بالجزيئات بأكاسيد

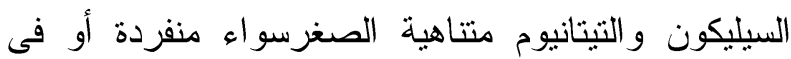

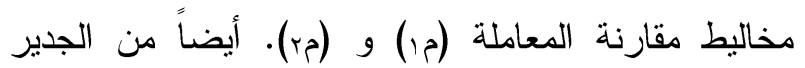

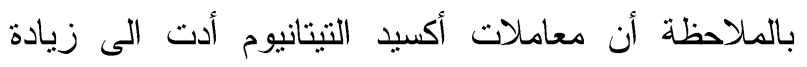

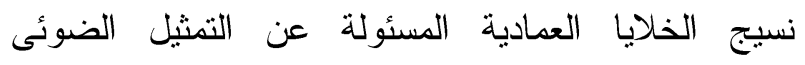

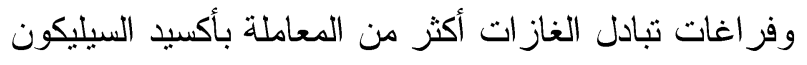

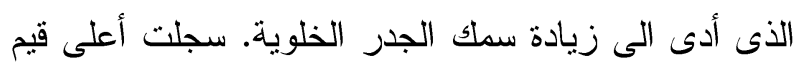

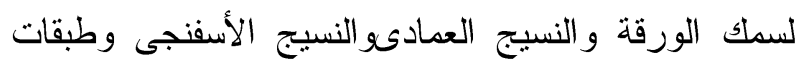
البشرة العلوية والسفلية وكذلك النسبة المئوية للساحة

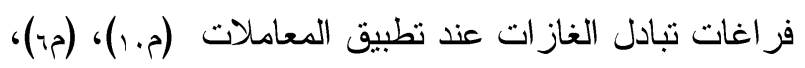
(مه)، (می)، (مـ) بالأضافة الى (مء) بالتزتيب.

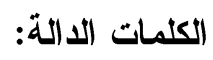

محصول الكوسة، أكسيد السليكون متتاهى الصغر، أكسيد التيتانيوم متتاهى الصغر، معدل حدوث وشدة

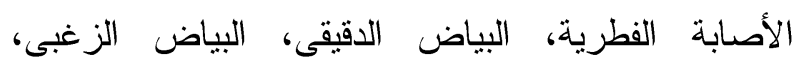
القياسات الظاهرية و التشريحية، المحصول ومكوناتة.

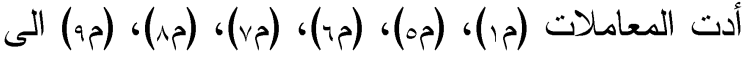

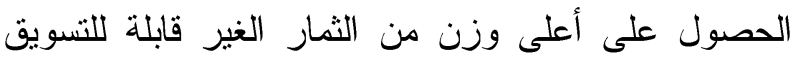
سواء أنتجت من النبات أو القطعة التجريبية بينما أقل القيم بالأضافة الى عدد الثمار الغير قابلة للتسويق تم الحصول

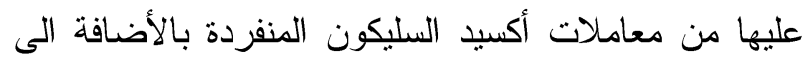
المعاملة (م. 1).

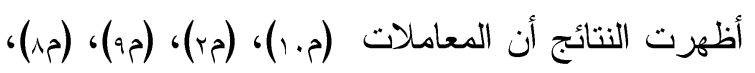

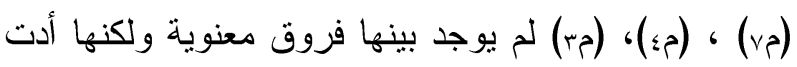

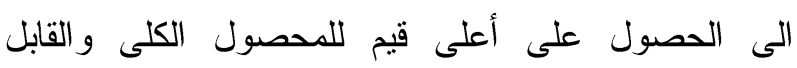
للتسويق سواء للنبات أو القطعة التجريبية أو الفدان مقارنة

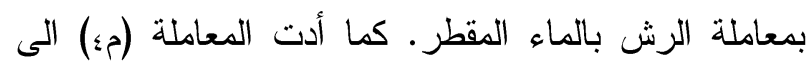
الحصول على أقل محصول غير قابل للنسويق.

أدت جميع المعاملات المختبرة وخاصة المعاملة (م.1) الى زيادة قيم صبغات التثثيل الضوئى و النترات و الفوسفات و البوتاسيوم معنوياً مقانة بالمعاملة (مر).

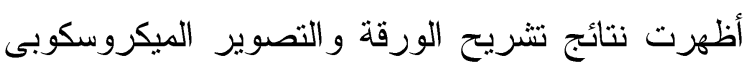
أن النباتات التى لم تعامل بأى من المواد المدروسة كانت

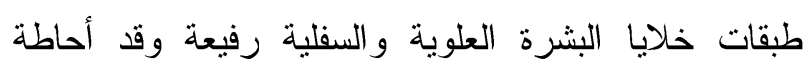
بأنسجة مشوهه ومدمرة نتيجة لوجود الأصابات الفطرية. على النقيض فأن سمك الورقة وطبقات البشرة العلوية 